\title{
A WILL OF THEIR OWN? \\ CHILDREN'S AGENCY AND CHILD \\ LABOUR IN BYZANTIUM
}

\author{
Youval Rotman \\ Tel Aviv University \\ ISRAEL
}

Date of receipt: $14^{\text {th }}$ of June, 2015

Final date of acceptance: $9^{\text {th }}$ of November, 2015

\section{Abstract}

This paper examines the relation between three concepts: a child's will, children's agency and child labour. Addressing the current debate about children's agency, this paper shows how these concepts were developed in Byzantine society in order to advance a religious agenda that encouraged the child to run away from home in favour of a new life in a monastery. Children were attributed with a will of their own and acted upon it before they reached the age of puberty. This perspective took the child out of the private sphere by attributing agency to it. The paper addresses the current debate about children's agency revealing the conceptualization of this term as motivated by an economic agenda in which the need to profit from the child's labour plays an important role.

\section{KeYWORDS}

Children's Agency, Child Labour, Child's Will, Byzantine Childhood, Byzantine Child.

\section{Capitalia verba}

Agentia Puerorum, Labor pueri, Voluntas pueri, Pueritia in Byzantio, Puer Byzantinus. 
Modern political discourse about child labour was developed in the $20^{\text {th }}$ century in relation to the human rights movement with the objective of eliminating the work of children. ${ }^{1}$ Nevertheless, in recent years a different attitude has become more and more prevalent in the international political discourse, which is cautious towards active political intervention in other cultures, and stresses instead the children's need and will to work in order to gain a sense of 'agency' for themselves. ${ }^{2}$ This term designates the link between a child's activity and a child's will, and allows perceiving the child as a social entity. A child's agency defines its ability to bring its will into action, and turns the child into an active agent. ${ }^{3}$

Acknowledging the social and psychological need of children to have agency is connected to the question of child labour, since children, some scholars argue, not only 'need' to work to support themselves and their families, but also 'want' to work. Here a fundamental distinction is being made between 'working children' and 'child labour'. ${ }^{4}$ While the second is perceived as exploitative and abusive, this perspective adheres to the fact that modern societies can and should be reconciled to the first. Work is the only means of survival for most working children today who express a desire to work. Work seems also to provide children with the means to change their situation by giving them greater independence and control over their life, or in other words agency. ${ }^{5}$ This term has recently been the subject of a study

1. White, Ben. "Defining the Intolerable. Child work, global standards and cultural relativism". Childhood, 6/1 (1999): 133-144. International organizations such as the International Labour Organization (ILO), International Programme on the Elimination of Child Labour (IPEC), United Nations International Children's Emergency Fund (UNICEF), World Health Organization (WHO), as well as various nongovernmental organizations (NGOs) and community-based organizations (CBOs), have acted over the last decades to stop the phenomenon of children working around the world, using legislation and other political and social means. See for example: Haspel, Nelien; Jankanish, Michele. Action against child labour. Geneva: International Labour Organisation, 2000; and other reports: International Labour Organization. "International Programme on the Elimination of Child Labour (IPEC)". International Labour Organization. 15 October 2015 <http://www.ilo.org/ipec/index.htm>. For a general summary: Bonnet, Michel. Travail des enfants: terrain de lutes. Lausanne: Page Deux, 1999.

2. Oswell, David. The Agency of Children: From Family to Global Human Rights. Cambridge (UK): Cambridge University Press, 2013: 3-36. On the use of the term see: Abebe, Tatek. "Interdependent rights and agency: the role of children in collective livelihood strategies in rural Ethiopia", Reconceptualizing Children's Rights: in International Development: Living Rights, Social Justice, Translations, Karl Hanson, Olga Nieuwenhuys, eds. Cambridge (UK): Cambridge University Press, 2013: 74-76.

3. Oswell, David. The Agency of Children...; Liebel, Manfred. A Will of Their Own. Cross-Cultural Perspective on Working Children. London-New York: Zed books, 2004; Hungerland, Beatrice; Liebel, Manfred; Milne, Brian; Wihstutz, Anne, eds. Working to Be Someone: Child Focused Research and Practice with Working Children. London-Philadelphia: Jessica Kingsley Publishers, 2007; Liebel, Manfred; Overwien, Bernd; Recknagel, Albert, eds. Working Children's Protagonism. Social movements and empowerment in Latin America, Africa and India. Frankfurt am Main: Iko-Verlag für Interkulturelle Kommunikation, 2001; André, Géraldine; Godin, Marie. "Child labour, agency and family dynamics: The case of mining in Katanga (DRC)". Childhood, 21 / 1 (2014): 161-174. Such voices were heard before, see: Jenks, Chris; James, Allison; Prout, Alan. Theorizing Childhood. Cambridge (UK): Polity Press, 1998: 3-21.

4. Most scholars refer to this distinction. For a summary and a theoretical point of view see: Jenks, Chris; James, Allison; Prout, Alan. Theorizing Childhood...: 108-115.

5. Schlemmer, Bernard, ed. L'enfant exploité. Paris: Éditions Karthala-Orstom, 1996. A different approach is taken by: Boyden, Ling and Myers (Boyden, Jo; Ling, Birgitta; Myers, William E. What Works for Working 
by David Oswell who analysed its history, its uses and implications in the different aspects of children's life in a modern society. Children's agency appears as a relative concept, inadequate for the problem that most children are facing. ${ }^{6}$

The present study shares Oswell's perspective, but examines the relation between the concept of children agency and child labour by focusing on the role it played in a medieval society: Byzantium. An analysis of the Byzantine case study will show that a child's will and a child's agency are highly speculative, and depend entirely on the ethical norms and cultural ideals dictated by society. Psychological research has shown that children aspire to fulfil their social and familial expectations, and that an independent will develops at adolescence. ${ }^{7}$ An analysis of the situation of children in Byzantine society will reveal that child's desires and child agency are constructed in the framework of a political, moral and economic agenda. Childhood is no longer believed to be a modern conceptual construction. ${ }^{8}$ This is also the case for the concepts of a child's will, work and agency. This article aims to reveal the relation between these three concepts by focusing on a period in history in which they played an important role. Analysing the relation between child labour, a child's will and agency, we will show that a child's will and a child's agency was used in Byzantium to legitimize child labour.

\footnotetext{
Children. Florence: Rädda Barnen-Unicef-International Child Development, 1998), who although calling for listening to children, do not call for delegating them the social responsibility for their lives (see especially chapter 6: "Mobilizing Society in the Best Interests of Working Children"). The same approach is found in: Burr, Rachel. Vietnam's Children in a Changing World. New Brunswick: Rutgers University Press, 2006.

6. See also: Ansell, Nicola. "Childhood and the politics of scale: descaling children's geographies?". Progress in Human Geography, 33/2 (2009): 190-209; Abebe, Tatek. "Interdependent rights and agency...": 74-76.

7. Starting from the book: Childhood and Society written by Erik Erikson (Erikson, Erik H. Childhood and Society. New York: W. W. Norton, 1950), and his work: Identity, Youth and Crisis (Erikson, Erik H. Identity, Youth and Crisis. New York: W. W. Norton, 1962) up to psycho-sociological works such as the one of Laura Purdy (Purdy, Laura M. In their best interest? The case against equal rights for children. Ithaca: Cornell University Press, 1992) and a sociological point of view in Rachel Brett and Irma Specht (Brett, Rachel; Specht. Irma. Young Soldiers: why they choose to fight. Boulder: Lynne Rienner Publishers, 2004).

8. See Philippe Ariès' argument in: Ariès, Philippe. L'enfant et la vie familiale sous l'Ancien Régime. Paris: Plon, 1960; Rosenthal, Joel T., ed. Essays on Medieval Childhood. Responses to recent debates. Donington: Shaun Tyas Publishers, 2007, especially the introduction (pages 1-12), as well as the historiographical chapter: Haas, Louis; Rosenthal, Joel T. "Historiographical Reflections and the Revolt of the Medievalists", Essays on Medieval Childhood. Responses to recent debates, Joel T. Rosenthal, ed. Donington: Shaun Tyas Publishers, 2007: 13-28.
} 


\section{What can the study of Byzantine society offer to the debate?}

Child labour was not an unusual phenomenon in Byzantine society. Byzantine children worked in their families' households and were employed by others. They had economic tasks in both rural and urban milieus, and their work was part of an economic system. ${ }^{9}$ Moreover, the economic value of their work was recognized and was considered a commodity: alongside children who remained at home, there were others who were pawned, exposed or enslaved. These were employed in a variety of tasks, some more and some less abusive. In all this Byzantine society offers nothing special to the modern debate on child labour. The elucidation Byzantium offers to our question about child's agency derives from two types of sources: its laws and its literature. Byzantine law originated from Roman law. Following its first codifications in late antiquity, it was constantly renovated and was remodelled as Christian law. As far as children were concerned, the law determined the legal boundary between childhood and adulthood, while dealing with social circumstances related to the child's everyday life.

Byzantine literature, in particular Byzantine Christian literature, was also interested in this boundary, but unlike the Byzantine legislator, attributed a face to the child. The term 'Christian literature' refers here to any literature with a Christian religious agenda. This includes Church's canons, patristic literature as well as hagiography. One of the subjects which this literature was concerned with was the encounter between the private sphere of the family and the Christian public sphere. Children and childhood sometimes became a subject in themselves, and were used to advance a cultural and religious agenda.

In defining the borderline between the private and the public in reference to children, Byzantine law and Byzantine literature established the ways in which children acted, and caused children to be perceived as social entities. This was particularly apparent in the period between the $5^{\text {th }}$ and the $11^{\text {th }}$ century, when both Byzantine law and literature were used to remodel the Empire's social institutions. We shall thus concentrate here on this period in order to reveal the development in the perception of the child in both juridical and literary sources. ${ }^{10}$ Hagiography, a new literary genre of early Christianity, had a cardinal role in making the child a social entity by attributing agency to it. Thus Byzantine children could henceforth

9. See: Nieuwenhuys, Olga. "The Paradox of Child Labour and Anthropology". Annual Review of Anthropology, 25 (1996): 237-251. Olga Nieuwenhuys reveals the ways in which the family in rural societies is economically dependent on non-remunerative child labour. In her study on working children in the countryside of Kerala, India, she has also demolished any possible idealization of children engaged in their family' economic organization. See: Nieuwenhuys, Olga. Children's Lifeworld: gender, welfare and labour in the developing world. London: Routledge, 1994. See also: Bales, Kevin. Disposable People: New Slavery in the Global Economy. Berkeley-Los Angeles-London: University of California Press, 1999: 149-194 (chapter 5: "Pakistan: When Is a Slave Not a Slave?").

10. This is also the case as far as the geopolitical context is concerned. Since this article deals with Byzantine civilization and the place it accorded to the child, we shall take as a geographical framework the Greek-speaking communities of the Mediterranean world. This will include texts from Egypt, Palestine, Syria and Southern Italy. 
have a will of their own and act upon it as independent agents. Two examples will demonstrate this.

The Life of Luke the Younger narrates the life of a peasant boy in $10^{\text {th }}$ century in central Greece. Luke is devoted to the labours of shepherding and farming, which include sowing the fields. ${ }^{11}$ Before he is twelve, Luke decides to leave his life and responsibilities as a peasant for a monastery. His choice is especially hard for his widowed mother, who expects him to take on the economic responsibility for the family after his father's death. This independent act leads him on his way towards sainthood. Another example is the story of George, the son of pawnbrokers from Constantinople, who, at the age of nine, is trained by his parents to master their profession. ${ }^{12}$ His apprenticeship trains him in the use of scales and weights and other technical utensils and procedures. But George slowly withdraws from his parents' home, and spends his time in church instead. His parents make a great commotion and succeed in bringing him back home by force.

These examples present agency as the child's ability to act upon an independent will, which is here a product of the boy's spiritual character. In both cases the child's agency is expressed in opposition to the family lifestyle, which includes an economic task. However, the child's agency here is a literary construction, which serves the author's moral agenda favouring running away from home and work towards a life in a monastery.

In order to analyse how child's agency is conceptualized we shall follow three lines of examination: (1) We shall start with a study of the child's economic activities in Byzantine society. Child labour was a built-in component of the Byzantine economy and a part of the family's economic organization. We shall see, however, that Byzantine children also worked outside of their family household, and their work was recognized as a commodity. This was linked to the representation of the child as a passive agent. (2) We shall then continue to examine the representation of the child as an independent social entity in Byzantine literature. In the two examples cited above, Byzantine literature attributes agency to the child. This proved to be a literary innovation of Byzantine hagiography in response to particular social needs. (3) The third line of examination will focus on a child's will as it was conceptualized in Byzantine mentality and laws. The child's capacity to possess an independent will is an essential component of its agency, and forms a necessary link between the child's agency and the context in which it is enacted. This study will conclude with an analysis of the relationship between agency, will and morality. The Byzantine child's agency was constructed within the framework of a moral agenda. An analysis of the ethical aspect of the term 'agency' will reveal that it is constructed in order to serve an agenda, and that in encouraging a child to act independently society uses the child in order to advance its cultural and social ideals.

11. The Life and Miracles of Saint Luke of Steiris, ed. and trans. Carolyn L. Connor, W. Robert Connor. Brookline: Hellenic College Press, 1994: 10 and following.

12. The Miracles of St. Artemios, ed. and trans. Virgil S. Crisafulli, John W. Nesbitt. Leiden-New York: Brill, 1997: 196-204. 


\section{Child labour in Byzantium}

The Greek language did not provide a means of categorization as far as children were concerned. Byzantine terminology used for children includes words such as

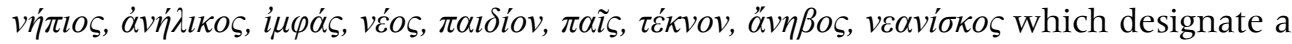
child, but not exclusively. The word $\pi \alpha \tilde{\imath} \varsigma$, for example, also designates a slave, while the word $\varepsilon_{\varepsilon}^{\prime} \kappa v o v$ refers to any offspring. Both are used for children and adults equally. In the same manner the word viós-son- does not designate a specific age, while the word vímıos, which normally refers to infant/minor, is also used metaphorically for someone childish. ${ }^{13}$

The law, on the other hand, makes use of the child/adult categorization in order to determine who is subject to jurisdiction and who is not. Following the definition of Roman law, Byzantine law set puberty (Latin pubertas, Greek $\ddot{\eta} \beta \eta$ ) at the age of twelve years for girls, and fourteen for boys. ${ }^{14}$ These were the minimum age for marriage. Infancy was set below the age of seven, while full juridical majority was granted to men at the age of twenty-five..$^{15}$ Childhood and adulthood were thus defined by the law according to an age criterion. In regard to the economic context of child labour in Byzantium, a few other categories must be taken into consideration: milieu (urban, rural); socio-economic status; juridical status (slave, freedman, free born); and gender (boys, girls). Child labour proved to be an integral component of any Byzantine economic organization.

The two stories cited above show a boy who is trained to follow the profession and economic responsibility of his parent/s, both in an urban and a rural milieu. ${ }^{16}$ To reveal the child's economic position within the family household we rely mainly on hagiographic sources here, since they are the most descriptive as far as everyday life and social reality are concerned. ${ }^{17}$ However, inheriting the family's

13. Arianti, Despoina. Kindheit in Byzanz. Emotionale, geistige und materielle Entwicklung im familiären Umfeld vom 6. bis zum 11. Jahrhundert. Berlin-Boston: De Gruyter, 2012: 28-50 (chapter 2: “Terminologie der Kindheit"); Prinzing, Günter. "Observations on the Legal Status of Children and the Stages of Childhood in Byzantium", Becoming Byzantine: Children and Childhood in Byzantium, Arietta Papaconstantinou, AliceMarie Talbot, eds. Washington D.C: Dumbarton Oaks, 2009: 15-34 (especially, see the terminological table at pages 21-22). See: Pache, Corinne Ondine. Baby and Child Heroes in ancient Greece. Champaign: University of Illinois Press, 2004: 7-8. See the confusing terminology in regards to children in: Life of st Philaretos the Merciful Written by His Grandson Niketas: A Critical Edition, ed. and trans. Lennard Rydén. Uppsala: Uppsala University Library, 2002: 60, 72, 84-86. The same vagueness in Latin terminology: Dixon, Suzanne. The Roman Family. Baltimore: John Hopkins University Press, 1992: 104.

14. Prinzing, Günter. “Observations on the Legal Status of Children...": 15-34.

15. Patlagean, Évelyne. "L'enfant et son avenir dans la famille byzantine (IVe-XIIe siècles)". Annales de démographie historique, 1 (1973) : 85-93; Antoniadis-Bibicou, Hélène. "Quelques notes sur l'enfant de la moyenne époque Byzantine (du VIe au XIIe siècles)". Annales de démographie historique, 1 (1973): 77-84.

16. Moschi, Joannis. "Pratum Spirituale", Patrologiae. Cursus Completus. Series Graeca Prior, ed. Jacques Paul Migne. Paris: Jacques Paul Migne, 1865: LXXXVII/3, col. 3092, where the boys are required to follow the trades of the father.

17. Chevallier Caseau, Béatrice. "Childhood in Byzantine Saint's Lives", Becoming Byzantine: Children and Childhood in Byzantium, Arietta Papaconstantinou, Alice-Marie Talbot, eds. Washington D.C: Dumbarton Oaks, 2009: 127-166; Arianti, Despoina. Kindheit in Byzanz...15-25; Hagiography offers to the historian rich information about daily social life in the Middle Ages precisely because the author needed to be 
economic responsibilities was, in fact, also a subject of the law. Urban economic life in Byzantium was organized in professional guilds. The Theodosian Codex, which compiles legislation from the $4^{\text {th }}-5^{\text {th }}$ centuries, contains the regulations of different guilds, specifically mentioning the offspring of artisans who are born into the profession' and must bear their fathers' fiscal status and economic position. This applies to the children of armourers, bakers, smiths, carpenters, artists, miners etc. ${ }^{18}$

This was the content of the law in the case of peasants as well. The coloni (in

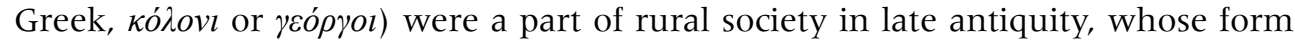
of dependence derived from the land that they cultivated, and forced them to pay the taxes attached to it. They, and their children after them, were bound to this fiscal responsibility, generation after generation. Children inherited this fiscal status from their parents and were attached to the fiscal obligation of the land. ${ }^{19}$ This was probably also the case of the $\pi$ ó $\rho \circ \kappa o l$, Byzantine dependent peasants. ${ }^{20}$ Ownership documents and cadastral registers as early as the $9^{\text {th }}$ century enumerate each family

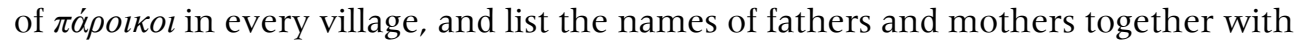
their sons and daughters. ${ }^{21}$ Girls in peasant families also shared in rural labours. ${ }^{22}$

As the examples cited above show, childhood was the period during which children were trained by their parents in order to continue the family's economic organization. Work was thus considered a necessary part of the child's education and training. In fact, the economic and educative objectives of the child's work could not be differentiated, especially in families of the lower and middle classes,

credible as far as the social and economic descriptions that he used: Patlagean, Éveline "Ancienne hagiographie Byzantine et histoire social". Annales. Économies, Sociétés, Civilisations, 23/1 (1968): $106-126$. 18. Codex Theodosianus, ed. Theodor Mommsen. Berlin: Weidmann, 1962: 745-746 (XIII.4.1-2 dated to 334 and 337); 560-561 (X.19.15 dated to 424).

19. Codex Theodosianus... : 190 (IV.21.3 dated probably to 320); 239-240 (V.18.1 dated to 419); Leges Novellae ad Theodosianum, ed. Paul M. Meyer. Berlin: Weidmann, 1962: 129-132 (Novellae Valientinaini number 31).

20. Lefort, Jacques. "Rural economy and social relations in the countryside". Dumbarton Oaks Papers, 47 (1993): 101-113; Lefort, Jacques. "The Rural Economy, Seventh-Twelfth Centuries", The Economic History of Byzantium, Angeliki E. Laiou, ed. Washington D. C.: Dumbarton Oaks Research Library, 2001: II, 236-310; Rotman, Youval. "Formes de la non-liberté dans la campagne Byzantine aux VIIe-XIe siècles". Mélanges de l'École française de Rome. Moyen Âge, 112/2 (2000): 499-510.

21. Lefort, Jacques; Oikonomidès, Nicolas; Papachryssanthou, Denise, eds. Actes d'Iviron. II : Du milieu du Xle siècle à 1204. Paris: P. Lethielleux, 1990; Lefort, Jacques. "Radolibos: Population et paysage". Travaux et Mémoires, 9 (1985): 195-234. On listing of the entire family in the fiscal inventories, see: Laiou, Angeliki E. "Peasant names in fourteenth-century Macedonia". Byzantine and Modern Greek Studies, 1 (1975): 71 95.

22. The Life and Miracles of Saint Luke of Steiris...: 10 and following. Byzantine literature usually places the pious girl in the interior of her home, often spinning at the wheel or weaving at the loom: Palladius, Bishop of Aspuna. Historia Lausiaca, ed. and trans. Gerardus J. M. Bartelink. Milan: Mondadori, 1974: 31; "Vie de sainte Athanasie d'Egine", Six inédits d'hagiologie Byzantine, ed. François Halkin. Brussels: Société des Bollandistes, 1987: 180; Sathas, Konstantinos N. Mesaionike bibliotheke. Hildesheim-New York: Georg Olms Verlag, 1972: I, 66 and following; Abrahamse, Dorothy. "Images of Childhood in Early Byzantine Hagiography". The Journal of Psychohistory, 6 (1979): 497-517. 
who were totally dependant on the child and its ability to work for the continuation and the existence of their economic organization. ${ }^{23}$

In her book Pauvreté économique et pauvreté sociale à Byzance, IV $V^{e}$ VII siècles, Évelyne Patlagean has revealed how a demarcation is defined within Byzantine society, between the poor family who could maintain an economically functioning social unit and the poor who were sited outside the social structure due to their economic situation. ${ }^{24}$ This demarcation was also evident as far as child labour was concerned. As Ville Vuolanto has argued, child slavery and child exposure were mostly the consequences of severe economic situations, and marked a crisis for poor families who could no longer function as a social and economic unit. ${ }^{25}$

Such was the case of Elias of Heliopolis, whose Life probably dates to the $10^{\text {th }}$ century. An orphan, he could not be trained by his father. At the age of eleven, he is apprenticed to a carpenter for a period of two years. ${ }^{26}$ He works in the workshop of his master and is paid a salary ( $\left.\kappa_{\kappa} \mu \nu \sigma \theta o \mu \alpha\right)$, which makes him a twelve-yearold employee. ${ }^{27}$ As far as girls' labour is concerned, spinning, weaving and sewing were also performed by young women outside their house, as apprentices in the production of cloth in Constantinople. ${ }^{28}$ In any case the family benefited also from the work of children who worked outside their family household, as is apparent in the following example in the Life of Elias of Heliopolis. When Elias turns twelve his master converts to Islam (the story is set in Damascus). Elias, who is afraid to be forced to convert, turns to his older brothers. They demand his salary from his employer for his year's work, but the master decline to pay, and refuses to let Elias go. ${ }^{29}$ Entrusting a boy to a professional as an apprentice, therefore, served a double purpose: the boy learned a profession, while the family derived an income from his labour. Elias' case suggests that there was a binding contract between the employer and the employee's family as to the period of work and salary. ${ }^{30}$ There was a specific juridical procedure for such contracts.

23. See: The Life of Saint Nikon, ed. and trans. Denis F. Sullivan. Brookline: Hellenic College Press, 1987: 34 and following.

24. Patlagean, Évelyne. Pauvreté économique et pauvreté sociale à Byzance, IVe-VII siècles. Paris-La Haye: Mouton, 1977.

25. Vuolanto, Ville. "Selling a Freeborn Child. Rhetoric and Social Realities in the Late Roman World". Ancient History, 33 (2003): 169-207; Miller, Timothy S. The Orphans of Byzantium. Child Welfare in the Christian Empire. Washington D.C: The Catholic University of America Press, 2003: 144-152; Trexler, Richard C. The Children of Renaissance Florence, Power and Dependence in Renaissance Florence. Asheville: Pegasus Press, 1998: I; Trexler, Richard C. "Infanticide in Florence: New Sources and First Results". Journal of Psychohistory, 1 (1973): 35-53.

26. Life of Elias of Heliopolis, ed. A. Papadopoulos-Kerameus. Pravoslavnij Palestinskij Sbornik, 19/3 (1907): 45. See: McGrath, Stamatina. "Elias of Heliopolis: The Life of an Eighth-Century Syrian Christian Saint", Byzantine Authors: Literary Activities and Preoccupations, John W. Nesbitt, ed. Leiden: Brill, 2003: 85-107.

27. For children as apprentices see: Palladius, Bishop of Aspuna. Historia Lausiaca...: 35.

28. Laiou, Angeliki E. "The Festival of 'Agathe', comments on the life of Constantinopolitan Women", Byzance. Hommage à André N. Stratos. Athens: N. Stratos, 1986 : I, $111-122$.

29. Life of Elias of Heliopolis...: 46-47.

30. Francine Michaud (Michaud, Francine. "From Apprentice to Waged-Earner: Child Labour before and after the Black Death", Essays on Medieval Childhood. Responses to recent debates, Joel T. Rosenthal, ed. 
The $\pi \alpha \rho \alpha \mu o v \eta$ was a special social institution, documented in the papyri since Antiquity, by which people hired themselves out as workers for a long period of time under a legal contract. ${ }^{31}$ As Vuolanto has shown, this juridical institution was used for pledging and leasing out children in late antiquity. ${ }^{32}$ The $\pi \alpha \rho \alpha \mu o v \dot{\eta}$ continued to be practised in Byzantine Egypt and Palestine in relation to children. The salary, mainly in goods, was paid to the child's father. ${ }^{33}$ Elias' story reveals the way in wich the family made use of the value of the child's labour. This made the child's work a commodity. In fact, in the medieval world children were commodities in themselves. One example of this was pawned children. ${ }^{34}$ Another was slave children.

Slavery was a juridical institution that Byzantium inherited from the Roman Empire. It was a common belief that this institution declined in late antiquity. However, sources from the entire medieval period show that slavery continued to be prevalent in the medieval Mediterranean societies. ${ }^{35}$ Slaves were employed in Byzantium in every possible economic and social position: in rural as well as urban milieus; in the private as well as the public sectors; by emperors, by the rich and by ordinary people. A person's economic position determined the number of slaves s/he had. Many of these slaves were children. Trade in children is well attested throughout the entire Byzantine period, including Arab, Slav and Bulgarian children, along with Greek children. ${ }^{36}$

Donington: Shaun Tyas Publishers, 2007: 73-90) analyzes labour contracts of children and reveals the decisive importance of the economic conjuncture and the social situation of the child for the conditions of its employment. This is inline with Patlagean's and Vuolanto's analysis of Byzantine society. According to Vuolanto, the exposure of the child to outside labour could have indicated the family's failure to function as an economic unit. Michaud's study, however, shows that the family did not end its responsibility towards the exposed child, but intervened in the terms of its employment, as is also clear from Elias' story.

31. Paramone: Editionen und Aufsätze von Mitgliedern des Heidelberger Instituts für Papyrologie zwischen 1982 und 2004, ed. James M. S. von Cowey, Bärbel Kramer. Munich: Saur, 2004; Montevecchi, Orsolina. “BGU IV 1139. Paramone e trophitis". The Bulletin of the American Society of Papyrologists, 22 (1985): $231-241$.

32. Vuolanto, Ville. "Selling a Freeborn Child...": 194-197.

33. Kraemer, Casper J., ed. Excavations at Nessana. Princeton: Princeton University Press, 1958: III, 156160 (P. Nessana 56).

34. References to this practice come also from Arab Ifriquiya and Egypt: Goitein, Shelomo Dov. $A$ Mediterranean Society. The Jewish Communities of the World as Portrayed in the Documents of the Cairo Geniza. Berkeley-Los Angeles-London: University of California Press, 1967: I, 259; which suits the rhetorical use of such cases as Vuolanto shows in regards to late antiquity.

35. Rotman, Youval. Byzantine Slavery and the Mediterranean World. Cambridge (Mass.): Harvard University Press, 2009; Rio, Alice. Legal Practice and the Written Word in Early Middle Ages: Frankish Formulae c. 5001000. Cambridge (UK): Cambridge University Press, 2009; Köpstein, Helga. Zur Sklaverei im Ausgehenden Byzanz. Philologisch-historische Untersuchung. Berlin: Akademie Verlag: 1966. Many of the Byzantine Novellae from the $6^{\text {th }}$ to the $12^{\text {th }}$ centuries referred to the institution of slavery, while reforming and renovating the juridical definitions of this institution (see: Rotman, Youval. Byzantine Slavery ...: 190-195 (Appendix B : "Legal Sources").

36. Rotman, Youval. Byzantine Slavery...: 57-81. Late antique sources also mention African children, see: Rotman, Youval. Byzantine Slavery...: 57. 
Children born to slave mothers were considered the property of their mother's owner. ${ }^{37}$ Other slave children, however, were freeborn. The $9^{\text {th }}-11^{\text {th }}$ centuries saw countless Byzantine inhabitants, among them many children, kidnapped, enslaved and then sold into slavery by pirates in the Mediterranean, as well as in the Balkan regions. ${ }^{38}$ Byzantine markets offered imported children of foreign origin who were sold as slaves. ${ }^{39}$ Orphaned children were the most vulnerable. Orphaned girls could be easily prostituted. ${ }^{40}$

Timothy Miller has revealed a sophisticated child care system that was developed in Byzantium following an imperial policy dated to Constantine to respond to the difficult situation of orphans. ${ }^{41}$ A famous Novella of Justinian from 535 mentions traders who travelled through the provinces and exploited the condition of unfortunate young women ( prostituting them in the Capital. ${ }^{42}$ The Novella states that even girls under the age of ten were forcibly prostituted, and attributes the term slavery to cases in which the young women were not paid and were held against their will. ${ }^{43}$ But girls were also procured by their parents. ${ }^{44}$

In fact, Byzantine children could also be sold into slavery by their parents. ${ }^{45}$ The practice is attested in the sources as far back as the $4^{\text {th }}$ century, and was mainly

\footnotetext{
37. The Digest of Justinian, eds. Paul Krüger, Theodor Mommsen. Philadelphia: University of Pennsylvania Press, 1985: I, 15 (Digesta I.5.5). Jus Graecoromanum, ed. Ioannes Zepos, Panagiotes Zepos. Darmstadt: Scientia Aalen: II, 199 (Prochiros Nomos XXXIV.5-7). Normally these children can be identified in the

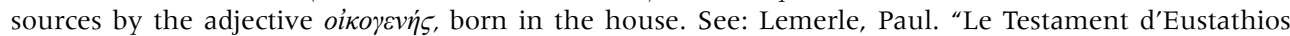
Boïlas (avril 1059)", Cinq Études sur le XI ${ }^{e}$ s. byzantin, Paul Lemerle, dir. Paris: Éditions du Centre National de la Recherche Scientifique, 1977: 15-63.
}

38. Rotman, Youval. Byzantine Slavery...: 47-48.

39. The Life of St. Andrew the Fool, ed. and trans. Lennard Rydén. Uppsala: Uppsala University Library, 1995 : II, 12-18. Although probably a legendary figure, his situation as a slave child sold in a Byzantine market was not uncommon. See: Rotman, Youval. Byzantine Slavery ...: 82-120.

40. Moschi, Joannis. "Pratum Spirituale...": LXXXVII/3, cols. 3097-3100.

41. Miller, Timothy S. The Orphans of Byzantium....

42. Novellae Justiniani, ed. Rudolf Schoell. Hildesheim: Weidmann, 1993: 105-109 (Novellae Justiniani number 14). See: The Council in Trullo Revisited, ed. and trans. George Nedungatt; J. Michel Featherstone. Rome: Pontificio Instituto Orientale, 1995: 166; the $86^{\text {th }}$ canon of the Council 'in Trullo' (from 692) excommunicates clerics who procure and bring up prostitutes.

43. Les récits édifiants de Paul évêque de Monembasie et d'autres auteurs, ed. and trans. John Wortley. Paris: Éditions du Centre National de la Recherche Scientifique, 1987: 126-136.

44. Procopius, Historia Arcana, ed. Gerhard Wirth. Leipzig: Teubner, 1964: 56. Vie de Théodore de Sykéôn, ed. and trans. André-Jean Festugière. Brussels: Société des Bollandistes, 1970: I, 3. For prostitution in Byzantium see: Irmscher, Johannes. "Die Bewertung der Prostitution im Byzantinische Recht", Gesellschaft und Recht im griechisch-römischen Altertum: eine Aufsatzsammlung, Mihail N. Andreev, ed. Berlin: Akademie Verlag, 1968: II, 77-94; Leontsini, Stavroula. Die Prostitution in frühen Byzanz. Wien: Universität Wien, 1989.

45. Codex Justinianus, ed. Paul Krüger. Hildesheim: Weidmann, 1997: 179 (IV.43 dated to 294), forbade such an act. Melluso, Marco. La schiavitù nell' età giustinianean. Besançon: Presses Universitaires de FrancheComté, 2000: 33 and following; Harper, Kyle. Slavery in the Late Roman World AD 275-425. Cambridge (UK): Cambridge University Press, 2011: 391-423 (chapter 10: "The enslavement of Mediterranean bodies: child exposure and child sale", especially page 392 and following). 
a desperate act of parents who were too poor to raise their children. ${ }^{46}$ In a letter from 527, Cassiodorus describes the annual fair held on Saint Cyprian's day in the Lucania, where peasants come from the countryside to sell their sons and daughters. ${ }^{47}$ A Novella of Justinian mentions creditors who used to take away the children of their debtors if the latter had no means to repay their debts, in order to use the children as slaves. ${ }^{48}$ The Novella proclaims that parental consent is necessary to perform this transaction, but testifies to the fact that children were taken away without their parent's consent..$^{49}$ An imperial Novella from 1095 attests to cases of Bulgarian parents who, in time of famine, sell their children. ${ }^{50}$

As these examples demonstrate, all throughout the period under consideration child slavery and child exposure were not only the act of a desperate parent. Children were kidnapped and sold into slavery since a demand for their labour existed. In most families of a stable economic position children worked and were part of the family's economic organization. Children would not be exposed or sold in families who could afford their keeping. Nonetheless, their capacity to work turned them into a commodity once they found themselves working outside the family unit.

Whether they worked within the family's household or were sent to work elsewhere, Byzantine children were not themselves remunerated. This accords with their representation as passive figures. The importance of rhetorical representation

46. Codex Theodosianu...: 182-183 (IV.8.6 dated to 323); Leges Novellae ad Theodosianum...: $138-140$
(Novellae Valientinaini number 33). Vuolanto starts with the juridical and social reality of selling and
exposing of the child in classical Rome and goes up to the $4^{\text {th }}-5^{\text {th }}$ centuries (Vuolanto, Ville. "Selling
a Freeborn Child...": 169-207). Holman, Susan, R. The Hungry Are Dying. Beggars and Bishops in Roman
Cappadocia. New York: Oxford University Press, 2001: 69 (footnote 23). For the juridical aspect see:
Buckland, William Warwick. The Roman Law of Slavery. Cambridge (UK): Cambridge University Press,
1970: 420-422; Kaser, Max. Das römisch Privatrecht. Munich: Beck, 1959: I, 60. On the practice in late
antiquity see: Basilii Magni. "Homilia II: In Psalmum XIV", Patrologiae. Cursus Completus. Series Graeca Prior,
ed. Jacques Paul Migne. Paris: Jacques Paul Migne, 1857: XXIX, col. 277; Glancy, Jennifer A. Slavery in
Early Christianity. Oxford-New York: Oxford University Press, 2002: 71.

47. Cassiodorus. Variae, ed. Theodor Mommsen. Berlin: Weidmann, 1894: 261-263 (Varia VIII.33); following: Barnish, Sam J. “Pigs, Plebeians and 'potentes': Rome's economic hinterland, c. 350-600 A.D.". Papers of the British School of Rome, 55 (1987): 157-185, 171.

48. Novellae Justiniani...: 682-683 (Novellae Justiniani number 134.7); Fichman, I.F. “Aspects économiques de la dépendance individuelle dans l'Égypte romaine et tardive", Gaudey, Jacqueline, trans. Esclavage et dépendance dans l'historiographie soviétique récente, Marie-Madeleine Mactoux, Évelyne Geny, eds. Besançon-Paris: Les Belles Lettres, 1995: 157-184. For the practice see volume 6 of the Greek Papyri in the British Museum: Bell, Harold Idris; Crum, Walter E., eds. Jews and Christians in Egypt. Vol. 6: The Jewish Troubles in Alexandria and the Athanasian Controversy illustrated by texts from Greek Papyri in the British Museum. London: British Museum Publisher, 1924: 72-80 (P. Lond. VI, 1915).

49. For the practice : Les récits édifiants de Paul évêque de Monembasie et d'autres auteurs, ed. and trans. John Wortley. Paris: Éditions du Centre National de la Recherche Scientifique, 1987: 132.

50. Jus Graecoromanum...: I, 341-346. Although the Novella indicates that anyone who can prove to be freeborn will be freed, it is hard to imagine how children who were either kidnapped or sold by their parents to slave traders and found themselves slaves far from home, could prove their freeborn status. See: Köpstein, Helga. "Zur Novelle des Alexios Komnenos zum Sklavenstatus (1095)", Actes du Xv Congrès International d'Études Byzantines (Septembre 1976, Athènes). Athens: Association Internationale des Études Byzantines, 1979: IV, 160-172. 
for economic and social dynamics has been demonstrated by Susan Holman. ${ }^{51}$ The representation of the child as a passive figure in Byzantine literature thus matched its exploitation. However, starting from the $6^{\text {th }}$ century, a new perception of the child developed in the Christian discourse that changed its passive figure completely by attributing agency to it.

\section{Children's agency in Byzantine literature}

Although classical Greek biographies include information related to the protagonist as a child, the interest in childhood is mainly confined to the protagonist's education. ${ }^{52}$ To the classical mind, character had three attributes: agency, rationality and responsibility. ${ }^{53}$ In the words of Stephen Halliwell: "action is held to manifest mind or character, while the latter is itself predicated on the basis of the virtues or vices embodied in action". ${ }^{54}$ Thus character is exhibited through action but depends on rationality, which is the product of adulthood. ${ }^{55}$ Following this reasoning, agency cannot be attributed to a child who has not reached a level of rationality and hence has no ability to possess a character. ${ }^{56}$ This is no longer the case in medieval Greek literature, namely in Byzantine hagiography. Although many hagiographical tales stay in line with their classical biographical antecedents, and do not put much emphasis on the saint's experience as a child, others choose to portray the protagonist as a holy agent already in childhood. In that, Byzantine hagiography proved to be innovative.

Saint Symeon the Stylite the Younger is a characteristic example of the new role children began to play in this literature as holy agents. He was born in 521 in Syria. The first part of his Life is dedicated to his childhood. Symeon has his first vision of Christ when he is but five years old. ${ }^{57}$ He wanders about away from home, enters a monastery, and begins his career as a stylite saint on top of a pillar when he is seven. His agency as a child is manifested in his asceticism, his combats against demons, his preaching and his healing of the sick, all of which he performs from

51. Holman, Susan, R. The Hungry Are Dying.... 69.

52. Pelling, Christopher. "Childhood and Personality in Greek Biography", Characterization and Individuality in Greek Literature, Christopher Pelling, ed. Oxford: Clarendon Press, 1990: 213-244. This is the case not only for fictional biographies such as Xenophon's Cyropaedia (“Cyrus' Education”), but also in Plutarch's biographies.

53. Halliwell, Francis Stephen. "Traditional Greek Conceptions of Character", Characterization and Individuality in Greek Literature, Christopher Pelling, ed. Oxford: Clarendon Press, 1990: 32-59.

54. Halliwell, Francis Stephen. "Traditional Greek Conceptions...": 32-59.

55. Gill, Christopher. "The Question of character-development: Plutarch and Tacitus". Quarterly, 33/2 (1983): 469-487.

56. There are exceptions of course, such as the legendary physical powers of the infant Heracles, but even in mythology the hero has no agency during childhood, and is portrayed merely as a hero-to-be.

57. La Vie Ancienne de S. Syméon Stylite le Jeune (521-592), ed. and trans. Paul van den Ven. Brussels: Société des Bollandistes, 1962 : I, 1-13. 
on top of his pillar. This is also the case of Theodore of Sykeon, who as a small boy is sent to school, but runs away of his own accord to seek a life of reclusion at the Martyrium of Saint George. ${ }^{58}$ Already as a boy he adopts a holy manner of living: fasting and refusing to take part in his family's meals. Other examples are Saint Luke the Younger and Saint Nikon 'Repent-Yourselves'. Both run away from home in order to pursue a holy career as monks, and both are followed by their parents who try to retrieve their runaway children. ${ }^{59}$ Such children, all boys, are portrayed as having an independent will, and as acting on it. Whether fictional or not, stories such as these manifest a change in the way children were portrayed in literature. ${ }^{60}$ The question is why such a change occurred.

Hagiography is a special literary genre. It is written as historical biography, but since it has a religious context and is a part of the cultural practice of the cult of saints, it differs from historiography. ${ }^{61}$ Hagiography has the characteristics of moral literature, for example of literature with a clear moral agenda. As far as children are concerned, the moral agenda sheds light on the special role attributed to the saint's childhood. Hagiographers started to develop this theme as early as the $4^{\text {th }}$ century, following the prototype of Jesus. ${ }^{62}$ This topos of the saint's spiritual character in childhood is further developed by the hagiographers between the $6^{\text {th }}$ and the $10^{\text {th }}$ century. It is important to state that this became possible only by attributing an independent will to the child. Hagiography is an extremely varied genre. Byzantine authors used it to describe both fictional and non-fictional figures, for either religious or literary objectives. However, all the authors who chose to narrate the saint's childhood did this in order to demonstrate the child's special spiritual character. This is emphasized by the child's will to disconnect himself from earthly life. The decision to lead a spiritual life is a rational one, and is made in childhood. The independent holy character is thus manifested in childhood. It is the product of the child's qualities that sets it apart from other children and drives the saint-tobe to independent action. Agency is thus connected to the child's character and aspirations. It is what we may call 'a spiritual agency,' that will correspond to the spiritual ideals this literature wants to advance.

58. Vie de Théodore de Sykéôn... : I, 6-13.

59. The Life and Miracles of Saint Luke of Steiris...: 8-12; The Life of Saint Nikon...: 38 and following.

60. The theme of a saint-to-be expressing his/her own will as a child and acting upon it, appears, of course, in other hagiographic narratives besides those mentioned here.

61. Hinterberger, Martin. “Autobiography and Hagiography in Byzantium”. Symbolae Osloenses, 75 (2000): 139-163; Lifshitz, Felice. "Beyond Positivism and Genre: 'Hagiographical' Texts as Historical Narrative". Viator, 25 (1994): 95-113. For its spiritual objectives see: Rapp, Claudia. "Storytelling as Spiritual Communication in Early Greek Hagiography: The Use of 'Diegesis'”. Journal of Early Christian Studies, 6/3 (1998): 431-448; Rapp, Claudia. "The origins of hagiography and the literature of early monasticism: purpose and genre between tradition and innovation", Unclassical Traditions: Alternatives to the Classical Past in Late Antiquity, Christopher Kelly, Richard Flower, Michael Stuart Williams, eds. Cambridge (UK): Cambridge University Press, 2010: 119-130.

62. Following Jesus' example in: Luke, 2: 41-49. Athanasius. La Vie d'Antoine, ed. and trans. Gerhardus Johannes Marinus Bartelink. Paris: Éditions du Cerf, 1994. 
Scholars have termed this sort of a child a puer senex, for example a child who possess the moral character of a wise old man, which makes him exceptional from childhood and pushes him to follow in the footsteps of Christ. ${ }^{63}$ However, to attribute a character of a wise old man (senex) to the boy (puer) is to ignore the agency this literature attributes to children. If the character of a grown man is exceptionally attributed here to a child, then his actions and decision to act would also be those of a grown man. ${ }^{64}$ But in fact, attributing agency to a child serves the hagiographer's objective in outlining a moral conflict.

Hagiography was created as an early Christian form of literature in late antiquity in order to commemorate the lives of the first martyrs, and hence had a strong religious and political agenda from its beginning. As far as children are concerned, the early martyrologies did not give them leading roles and rarely mentioned them. One of the most famous children's martyrdoms is the Passion of the three sisters Pistis, Elpis and Agape, and their mother Sophia. It is the story of a Christian family (the girls are twelve, ten and seven), who refuses to sacrifice to Artemis, suffers horrible tortures and is executed. The mother urges her smaller seven-year-old daughter: "my hope for you is a crown worthy of those of your two sisters". Little Agape does not fail her mother and speaks up against the emperor. She then suffers horrible tortures and is finally executed. ${ }^{65}$

The story is modelled on the legend of the Maccabee mother and her children who refuse to follow the orders of the Seleucid King and to eat the forbidden pork (Maccabees, II, 7:20-23). This story from Maccabees II is specifically used as a reference in late antique matrytologies. ${ }^{66}$ In addition, the authors refer also to the Biblical binding of Isaac, the archetype of a parent who is willing to sacrifice their own child for their beliefs (Genesis, 22:1-18). This becomes especially significant in the case of the martyr children. Their stories serve the martyrology's political agenda. However, although the martyr children adhere to the ideals of their time, their will is not at all

63. Carp, Teresa C. “'Puer Senex' in Roman and Medieval Thought". Latomus, $39 / 3$ (1980): 736-739; Hatlie, Peter. "The Religious Lives of Children and Adolescents", Byzantine Christianity: A People's History of Christianity, Derek Krueger, ed. Minneapolis: Fortress Press, 2006: III, 182-200; Kalogeras, Nikos. "What do they think about children? Perceptions of childhood in early Byzantine literature". Byzantine and Modern Greek Studies, 25 (2001): 2-19. All focus on the pious child, not on the rebel child who runs away from home and family. The 'wise child' was already appreciated in Roman society. See: Dixon, Suzanne. The Roman Family...: 105.

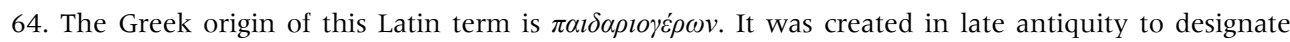
young holy men in their 20s and 30s, who were admired by their high level of asceticism worthy of old ascetics. According to Palladius and Sozomenus, who first mention the term, it was attributed to Saint Makarios of Egypt when he was thirty years old by his fellow monks, hence not at all a child: Palladius, Bishop of Aspuna. Historia Lausiaca...: 17; Sozomène, Histoire Ecclésiastique, ed. and trans. Joseph Bidez. Paris: Éditions du Cerf, 1996: III, 14.

65. Select Narratives of Holy Women from the Syro-Antiochene or Sinai Palimpsest: As written above the old Syriac Gospels by John the Stylite, of Beth-Mari-Qanūn in A.D. 778, ed. and trans. Agnes Smith Lewis. London: C. J. Clay and Sons, 1900: I, 1 18-144; Halkin, François. Légendes grecques de martyres romaines. Brussels: Société des Bollandistes, 1973: 179-228; Girardi, Mario. “Le fonti scritturistiche delle prime 'recensiones' greche della 'passio' di S. Sofia". Vetera Christianorum, 20 (1983): 47-76.

66. Musurillo, Herbert. The Acts of the Christian Martyrs. Oxford: Clarendon Press, 1972: 212-213, $230-231$. 
independent, but derives from the parent's will. It is the parent who encourages the child to hold to its faith. Just like the binding of Isaac, their martyrdom emphasizes more than anything else their parents' faith and endurance. ${ }^{67}$ They are caught in the combat of the parent against the emperor or king and take the side of the parent.

The Passion of Vitus presents a different combat. Vitus is a seven-year-old Sicilian boy, who refuses his father's entreaties to return to paganism, confronts the emperor Diocletian, and is martyred for his principles. ${ }^{68}$ Although his martyrdom differs from that of the children who die to testify their parents' faith, in both cases the martyr child's agency is manifested in opposition to a third (be it the emperor, the king or the parent). The protagonist child adheres to the spiritual-religious ideal which challenges the authority of either the political leader or the child's parent. The hagiographer builds a confrontation for the child to express his agency. In this way this literature attributes agency to children in order to outline a social conflict. This is evident in the Passion of Lucillianus, in which four children following in the martyr's footsteps, and are decapitated after proclaiming their wish to share his destiny. ${ }^{69}$

Just like the martyr children, the saints who run away from home in their childhood are also following the religious ideals of their time. Their running away from home has an objective: the monastery. The conflict which the child is caught up in here confronts the monastic life with the ordinary family life. This was not a new theme. Cutting off ties with the earthly world was already an ideal of early Christianity. This included the severing of biological, social and economic ties. Monasticism challenged the family nucleus as a unit from its beginning. ${ }^{70}$ Christian believers left their families and their socio-economic positions in favour of a monastic family and a monastic way of life. Not all saints' Lives were uniform in their treatment of the role of the nuclear family. Some accepted family links and some rejected them. ${ }^{71}$ Not all of them confronted the child's will with the parents' will. Most of the hagiographers present their protagonist as a pious and diligent child at home. Nevertheless, when the author does set up such a confrontation for the child, it is always the child's will which prevails, since the child's duties towards God precede its duties towards its parents. ${ }^{72}$ When the child is caught up in a conflict between loyalty to his parents and to God, the child is forced to act upon a will of its own. The act is running away from home, which is directed against the parent. The duties towards the parent are performed in the family household; the duties towards God in the monastery. As such they contradict one another. We saw

\footnotetext{
67. In contrast Jewish midrashic literature made Isaac a thirty-three-year-old man, which is important in order to argue for his awareness and acceptance of his fate.

68. Acta Sanctorum Iunii. Paris: Société des Bollandistes, 1698: II, 1021-1026 (Passio S. Viti).

69. "They happen do be my children (paidia)", says Lucillianus, "in both their age and intention to pursue Christ". Delehaye, Hippolyte. "Saints de Thrace et de Mésie". Analecta Bollandiana, 31 (1912) : $187-192$.

70. Talbot, Alice-Marie. “The Byzantine Family and the Monastery”. Dumbarton Oaks Papers, 44 (1990): $119-129$.

71. Kazhdan, Alexander. "Hagiographical Notes". Byzantion, 54 (1984): 176-192.

72. The Life and Miracles of Saint Luke of Steiris...: 24.
} 
that at home these duties comprised economic tasks. This was also the case in the monastery.

In the $4^{\text {th }}$ century, Basil of Caesarea set the age of entering a monastery at sixteen or seventeen years. ${ }^{73}$ This did not become a binding law. In fact, until the end of the $7^{\text {th }}$ century, no legislative regulation limited the age of joining a monastery for either boys or girls. The first legislative action in this matter was taken in the ecumenical council of 692, which set the age at ten years for both sexes. ${ }^{74}$ This regulation was repeated two hundred years later. ${ }^{75}$ Nevertheless, the rule was not always respected..$^{76}$

The examples cited above exemplify children who all came to the monastery in order to pursue a new life of spiritual and religious submission. Monasteries also took in orphans as well as abandoned children. ${ }^{77}$ Once in the monastery, these children obviously received a religious education. As part of their education, they were assigned to a person who served as their spiritual guardian and master. That meant obedience, service and labour. All the sources cited above emphasize that these future saints enjoyed serving their admired masters. Other sources give a closer and somewhat different picture of the kinds of labour that children were required to carry out in monasteries. Children performed cleaning and washing services. ${ }^{78}$ They also served as personal servants to their masters. In this respect they were no different from adult monks, whose duty was to wait on others. However, children proved to be very useful in these tasks for two reasons. First, it was an easy way to integrate them into monastery life and teach them how to be submissive inside the monastery. Secondly, it was a form of compliance which they were used to in their original homes.

The replacement of old family ties with new monastic family ties also meant the replacement of one form of obedience with another. This is exactly the question that the hagiographic literature deals with: should the immediate loyalty of a child be to his biological father and family, or to God through the mediation of a new monastic father and family. Moreover, the labour that these children were required to do was essential to the functioning of the monastery. Even in remote

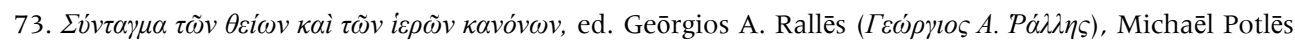

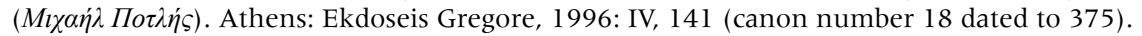

74. The Council in Trullo Revisited...: 119-121; Greenfield, Richard. "Children in Byzantine Monasteries: Innocent Hearts or Vessels in the Harbor of the Devil?", Becoming Byzantine: Children and Childhood in Byzantium, Arietta Papaconstantinou, Alice-Marie Talbot, eds. Washington D.C: Dumbarton Oaks, 2009: 253-282; which opens with a late Byzantine debate about whether to accept children in monasteries.

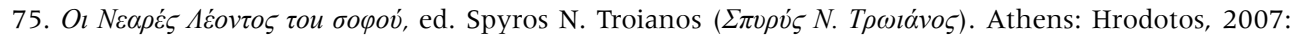
60-62 (Novella number 6 as edited by Pierre Noailles).

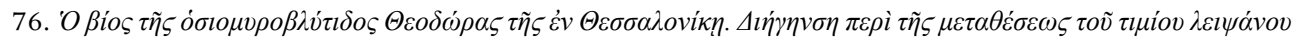

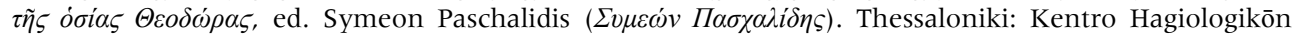
Meletōn, 1991: 21 (chapter 9).

77. Miller, Timothy S. The Orphans of Byzantium...: 153-161; Greenfield, Richard. "Children in Byzantine Monasteries...": 274-276.

78. The Lives of Simeon Stylites, ed. and trans. Robert Doran. Collegeville: Cistercian Publications, 1992: 117. 
monasteries where there was only a single monk, we find a little boy who waits upon the monk by polishing his shoes, cleaning his cell, and opening the door for him. ${ }^{79}$ In the $9^{\text {th }}$ century, Theodore Stoudite forbade monks from having immature disciples $(\mu \varepsilon \imath \rho \alpha \dot{\kappa} \iota \alpha \mu \alpha \theta \varepsilon \dot{\tau} \tau \alpha)$ with them in the cell. ${ }^{80}$ However testaments from the $10^{\text {th }}$ to the $14^{\text {th }}$ centuries preserved in Athos, reveal abbots who had retinues composed

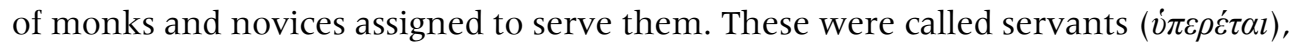

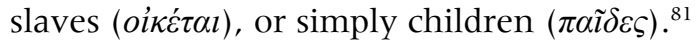

This economic responsibility was part of the social role of novices in monasteries, in convents as well as in churches. ${ }^{82}$ Monks who enjoyed great prestige and high socio-economic positions had personal servants of their own, and could also bring their own servants or slaves with them to the monastery. ${ }^{83}$ This was also the case of rich women who brought along their female slaves when they entered convents. ${ }^{84}$ Nuns and novices spun and wove in the convents, just like young girls and women in private homes, and were also required to carry out other economic tasks such as grinding grain at the mill. ${ }^{85}$

These examples reveal that the monastery was not a refuge from work. In fact, they suggest the opposite: that the monastery had a lot to gain from runaway children. Just like the family household, the monastery's existence and continuous functioning depended on an upcoming generation. Since there were no biological possibilities, a constant integration of new novices was essential. Monasteries profited from runaway children, thanks to the fact that children and their labour were commodities.

The hagiographic narratives cited above were mostly written by monks. Since this was also an exemplary literature, the hagiographers set in their stories models for imitation. ${ }^{86}$ This literary construction defined a limited space for the child to express a very specific wish, and thus subdued the child's agency to a will that was

79. The Lives of Simeon Stylites...: 117

80. Studitae, Theodori. "Testamentum", Patrologiae. Cursus Completus. Series Graeca Prior, ed. Jacques Paul Migne. Paris: Jacques Paul Migne, 1903: XCIX, col. 1821 A (“article 18”).

81. Archives de l'Athos, Actes de Lavra: I. Des origines à 1204, ed. Paul Lemerle, André Guillou, Nicolas Svoronos. Paris: Lethielleux, 1970: 151-155, 177-179 (documents number 19, 26, from 1016, 1030); Actes de Xenophon, ed. Denise Papachryssanthou. Paris: Lethielleux, 1986: 59-75 (documents number 1 from 1089); Acta et diplomata graeca medii aevi sacra et profana, ed. Franz Miklosich, Joseph Müller. Vienna: Gerold, 1890: VI, 81-90, document number 20 of Patmos, is a testament from 1093 that mentions a monk who had his own $\pi \alpha i \delta i \alpha$ with him. Greenfield, Richard. "Children in Byzantine Monasteries...": 274-276.

82. Talbot, Alice-Marie. "The Posthumous Miracles of St. Photeine". Analecta Bollandiana, 112 (1994): 85-104, 95; Nicétas Stéthatos. Un grand mystique byzantin: vie de Syméon le Nouveau Théologien, ed. Irénée Hausherr, Gabriel Horn. Rome: Pontificio Instituto Orientale, 1928: 53.

83. John of Ephesus. Lives of the Eastern Saints, ed. and trans. Ernest Walter Brooks. Turnhout: Brepols, 2003: I, 665-666 (Patrologia Orientalis IXC, XVII).

84. Acta Sanctorum Novembri. Paris: Société des Bollandistes, 1910: III, 790-813 (Vita prima S. Matronae, chapter 44); John of Ephesus. Lives of the Eastern Saints...: I, 290 (Patrologia Orientalis IXC, XVII).

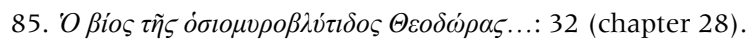

86. Greenfield, Richard. "Children in Byzantine Monasteries...": 269-270; Hennessy, Cecily. Images of Childhood in Byzantium. Aldershot: Ashgate, 2008: 111-142. 
not his to begin with. In this respect, the difference in the literary representation of children who run away from home to join the monasteries on the one hand, and of orphans who are reared in monasteries and orphanages on the other hand is very significant. ${ }^{87}$ Only the first are presented as possessing a will of their own; while in order to protect children and develop a care system the imperial laws outlined the helpless situation of the exploited orphans. ${ }^{88}$ To develop the topos of the child who runs away from home, the child's will needed to be acknowledged. In other words, the capacity to independent action depends on possessing a will; not any type of will but a will to act in a certain way. In contrast, in the Life of Zosimos the Bishop of Syracuse, Zosimos the child runs away from the monastery where his parents left him as a boy simply because he misses them. ${ }^{89} \mathrm{He}$ is stopped by the Virgin who punishes him and makes him go back to the monastery with the promise never again to attempt an escape. As this exceptional example shows, the question whether Byzantine children ran away from home to join monasteries or not is not pertinent here for the analysis of the child's agency as a cultural construction. In any case when such a confrontation is presented, one act is legitimized while the other is delegitimized. In other words, the child's agency is here constructed according to a moral distinction between positive and negative wills. This lead us to the following question: how is such a process of legitimization created? What determines that a child's will is legitimized? In other words, what determines that a child will be responsible for his or her acts? This depends on the child's capacities to make a moral decision. In what follows we shall analyse the relation between a child's agency and its ability to differentiate right from wrong.

\section{What is a child's will?}

In the $6^{\text {th }}$ century, Justinian's Code repeats the classical Roman definitions according to which puberty is set at twelve years for girls and fourteen years for

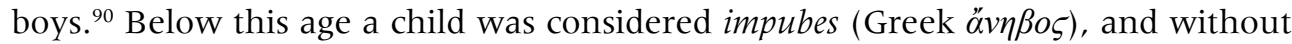
a juridical personality. This coincided with the fact that under this age the child was incapable of procreative sexual intercourse and could not be married. Puberty did not elevate the child to a level of full adulthood. Pubes/eres who had juridical personality and could be married, were considered minors (minor/res) up to the age of twenty-five, and could not take part in business transactions without a father

87. Miller, Timothy S. The Orphans of Byzantium...: 127-132, 152-161.

88. Novellae Justiniani...: 105-109 (Novellae Justiniani number 14). Miller, Timothy S. The Orphans of Byzantium...: 148-154.

89. I am grateful for Mario Re for this reference to the third version of the Life: Re, Mario. “La 'Vita' di s. Zosimo vescovo di Siracusa: qualche osservazione". Rivista di studi bizantini e neoellenici, 37 (2000): 29-42, especially 40 (footnote 41 ).

90. Codex Justinianus...: 231 (V.60.3 from 529) 
or a guardian. ${ }^{91}$ Having a juridical personality also meant that a minor was liable to penalty in the eyes of the law, and was held responsible for his or her actions. Under the age of puberty, the child was regarded as incapable of criminal intent (doli incapax). In regard to the child's liability to penalty, this definition proved to be flexible.

This was a subject of juridical discussions, starting probably from the $2^{\text {nd }}$ century AD. ${ }^{92}$ The jurists cited in Justinian's Digest deal with the possibility that a child who has not reached puberty might be liable to penalty. This is determined by the child's capacity to carry out an intentional action. It was clear to the Roman jurists that below the age of seven years the child, who was considered an infant (incapable of speech), could not carry out intentional actions or have an independent will. Wilful fraud (dolus malus), however, could be applied in special circumstances to a child who was between infancy and puberty. The jurists of the $2^{\text {nd }}$ century cited in the Digest affirm that in the later stages before puberty (proximus pubertati), a child is capable of fraud and guilt. ${ }^{93}$

These juridical definitions were integrated into Byzantine law with no special or further discussions. ${ }^{94}$ In the $8^{\text {th }}$ century, the Ekloga affirms that someone who has

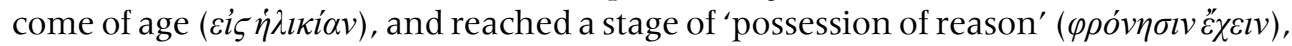
cannot withdraw from it. ${ }^{95}$ The Ekloga also determines the indemnity from the death punishment of a boy guilty of a passive homosexual act if he was under the age of twelve, since "his age manifests that he did not know what he was doing".${ }^{96}$ The law did not take into consideration the child's will. What made the act intentional and determined the liability to penalty was not the fact that it was an act of will, but the intellectual capacity to understand it. Homosexuality became liable to penalty with the Christianization of the Empire. Christianity added a religious dimension to the law, but did not change the Roman definitions of liability to penalty. Nevertheless, being a moral religion, Christianity, needed to establish what constituted a sinful act, and determine the age from which an act can be considered as a sin.

Similarly to Judaism early Christianity needed to establish its own age boundary between childhood and the life of religious adulthood. Baptism, which could

91. Kaser, Max. Das römisch Privatrecht. Munich: Beck, 1959: II, 78-81. That meant that a minor could be in possession of property, but could not administer it. Lemosse, Maxime. "L'incapacité juridique comme protection de l'enfant en droit romain". Recueils de la Société Jean Bodin pour l'histoire comparative des institutions, 35 (1975): 247-255.

92. Prinzing, Günter. "Observations on the Legal Status of Children...": 23-30; Thomas, Joseph A. C. "Delictal and Criminal Liability of the Young in Roman Law". Recueils de la Société Jean Bodin pour l'histoire comparative des institutions, 38 (1977) : 9-31.

93. The Digest of Justinian...: IV, 743 (Digesta XLVII.2.23); following: Rawson, Beryl. Children and Childhood in Roman Italy. New York: Oxford University Press, 2003: 138. See also: Perrin, Bernard. "L'apparition du 'proximus puberti' en droit romain classique", Synteleia: Vincenzo Arangio-Ruiz, Vincenzo Arangio-Ruiz, Antonio Guarino, Luigi Labruna, eds. Naples: Jovene, 1964: 469-474.

94. Antoniadis-Bibicou, Hélène. “Quelques notes sur l'enfant...” : 77-84.

95. Ecloga: das Gesetzbuch Leons III und Konstantinos V, ed. Ludwig Burgmann. Frankfurt am Main: Lowenklau-Gesellschaft, 1983: 170 (Ekloga 1.4.2).

96. Ecloga ...: 238 (Ekloga, 17.38 and 17.39). 
be performed at any age, could not define such a boundary. The same goes for participation in the Eucharist, which had no minimum age. ${ }^{97}$ In his Questions $\theta$ Answers, Timothy of Alexandria deals with the case of a catechumen who takes the Eucharist before his or her baptism. ${ }^{98}$ This article's title (in English), "Regarding a

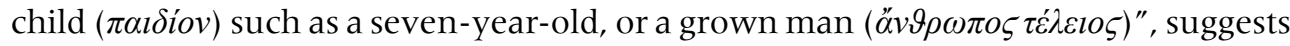
that conversion, which required a verbal declaration of faith, was not performed below the age of seven - the end of infancy.

In his study of the way childhood was perceived in Eastern patristic thought Graham Gould terms 'the capacity of the infant soul for religious understanding or moral development' as 'the anthropological question of childhood'. He defines the condition of childhood in this respect in terms of three interrelated factors:

firstly, the development of a child's soul in terms of its possession, or lack of possession, of faculties such as reason and desire ( $\dot{\varepsilon} \pi \mathrm{i} \theta v \mu i \dot{\alpha} \alpha)$, which were considered to be among thecomponents of the human soul; secondly, the extent to which a child's soul is open to the same temptations, desires, or passions as that of an adult; thirdly, the extent to which children are capable of understanding religious ideas and precepts, or may be held to deserve reward or punishment for their actions. ${ }^{99}$

In the writing of the Church Fathers, these three factors of the child's rational development became connected to its sexual development. Origen is the first to argue that children have not yet fully attained the possession of reason, thanks also to their freedom from sexual temptation. ${ }^{100}$ Both Clement and Origen affirm the freedom of the infant soul from both passion and reason. Their followers separate reason from desire, and stress the importance of the first, which becomes essential to overcome the second. John Chrysostom, Basil of Ancyra and Jerome outline in their writings the importance of early education that must precede the development of the sexual sense in order to prevent the sins that can derive from it. According to Basil of Ancyra 'the law of sin' can be equated with sexual desire. Sin is here set to the age of puberty. In the Life of Mary of Egypt, the heroine leaves her parents at the age of twelve to embark on a sinful life as a prostitute in Alexandria. ${ }^{101}$ At the age of twelve she is no longer considered a child. It is striking how the definition of criminal intent in the Empire's code of laws, which was based on the age of puberty, receives here a new interpretation according to the Christian conceptualization of the sexual desire as a $\sin .^{102}$

97. Moschi, Joannis. "Pratum Spirituale...": LXXXVII/3, cols. 3080D-3084A.

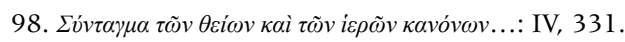

99. Gould, Graham. "Childhood and Eastern Patristic Thought: Some Problems of Theology and Theological Anthropology". The Church and Childhood, Studies in Church History, 31 (1994): 39-52, especially, 39-40.

100. Gould, Graham. "Childhood and Eastern Patristic Thought...": 41-43.

101. Moschi, Joannis. "Pratum Spirituale...": LXXXVII/3, col. 3712.

102. See the same construction of the sexual lust of a girl who has just come to age and maturity as part of Procopius' slander of Theodora: Procopius, Historia Arcana...: 56-57. The proximity of puberty and the first intercourse was already noted by the Roman physician Cornelius Celstus in the $1^{\text {st }}$ century BC 
Sins, of course, were not necessarily a product of sexual desire. And the Church Fathers referred in their writing directly to the development of the capacity to differentiate right from wrong. In the $4^{\text {th }}$ century Basil of Caesarea stresses the importance of education in moulding the mind in childhood, and in particular of schools in monasteries, which may offer a perfect environment. ${ }^{103}$ Religious responsibility thus starts with reason before puberty, and is developed together with a capacity to choose. As noted above, Justinian's Digest cites the $2^{\text {nd }}$ century jurist Julian, according to whom children (impubes) are considered capable of criminal intent, if they could be shown to have understood the nature of their deed. ${ }^{104}$ A Christian echo of this view is given by Timothy of Alexandria. Who writes in his Questions $\theta$ Answers: "Q: From what age are sins decided by God? A: From the knowledge and judgment of each one, some from the age of ten, others older". ${ }^{105}$ Sin here is not a product of the sexual drive, but is determined by God, and can precede puberty. As noted above, this age was taken in the $7^{\text {th }}$ century as the minimum age of entering a monastery. A scholion to the Nomocanon comments on the discussion in the Digest about accusations of forgery and adultery relating to a child who had not reached puberty. ${ }^{106}$ It states that although puberty is set at the age of twelve or fourteen years, a child who had

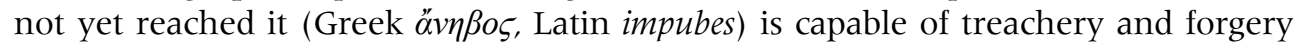
starting from its seventh birthday. The scholion states, however, that between the ages of seven to twelve or fourteen years, the transgressor is not punished as a grown man ( $\tau \dot{\lambda} \lambda \varepsilon \imath \circ \varsigma)$, but punished in moderation.

In the $12^{\text {th }}$ century, in his own Questions $\theta$ Answers, Theodore Balsamon states, nevertheless, in the matter of confession of sins, that although according to the laws the sins of those who did not yet reach puberty are to be forgiven, it is advised "that after their sixth birthday (for example starting from their seventh year) both males

(Rawson, Beryl. Children and Childhood...: 141). See: Avot de-Rabbi Nathan, ed. Solomon Schechter. New York: Feldheim, 1945: 16, 32-63; Kaplan, Zvi. “Bar Mitzvah, Bat Mitzvah”, Encyclopaedia Judaica, Michael Berenbaum, Fred Skolkin, eds. Detroit: MacMillan, 2007: III, 165.

103. "When reason enters in and habits of choice develop, they will take their course from the first elements learned at the beginning and from traditional forms of piety; reason proposing that which is beneficial, and habit imparting facility in right action. At this point, also, permission to make a vow of virginity should be granted, inasmuch as it is now to be relied upon, since it is the individual's own choice and the decision follows upon the maturing of reason". The Fathers of the Church: A New Translation (Patristic series), trans. M. Monica Wagner. Washington D.C.: The Catholic University of America Press, 1962: 9, 267.

104. The Digest of Justinian ...: IV, 743 (Digesta XLVII.2.23).

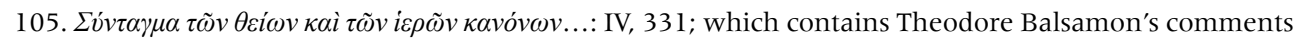

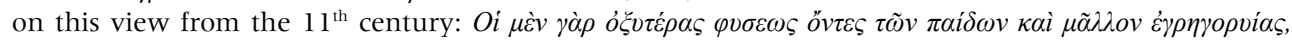

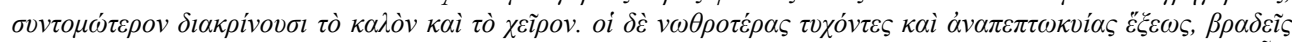

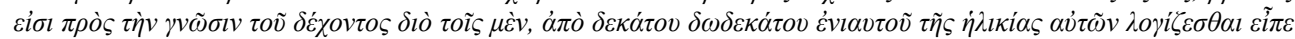

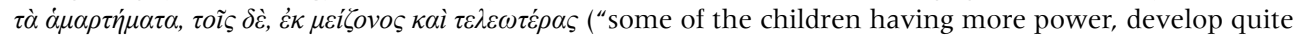
fast...., others who develop more gradually... are delayed in understanding what is needed. Thus with the former, their sins are counted from their tenth birthday ["twelve years" in a different version], but with the others, only when they are older and full-grown").

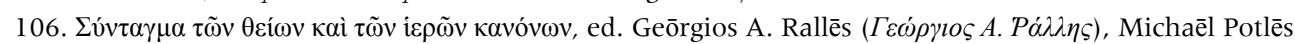

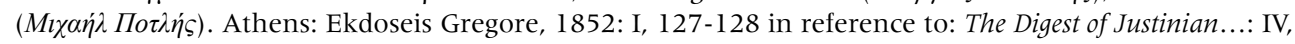
828 (Digesta XLVIII.10.22). 
and females will be liable by confession to amend themselves and to become holy". ${ }^{107}$ He bases his argument on a previous council's decision, according to which a sevenyear-old girl is capable of seducing a man. Religious responsibility, being a moral quality, is composed of two components: the capacity for sin, and the capacity for sanctity. However, what the juridical and patristic sources suggest is that religious responsibility was determined by the child's capacity to act intentionally. This process did not push down the borderline between childhood and adulthood. The borderline stayed defined at puberty. But there was a demonstrable tendency to attribute individual intent to the child at an ever earlier age. A similar process attributed the capacity of consent to marriage also to children at an earlier and earlier age.

Évelyne Patlagean has shown how the flexibility of the age criterion served the family in its social planning for expansion. ${ }^{108}$ Marriage required the two spouses' sexual maturity, and was set at the age of puberty. However, betrothal could be performed in a much earlier age, and depended on the consent of the boy and girl to get married in the future. Unlike puberty, the age of consent proved to have a flexible definition. Patlagean shows the family's tendency to push it down to the age of six or seven years, in order to use the offspring for the family's social projects. This reveals the way in which a new definition for a child's will is being set in order to fulfil a social need. The Church, an active partner in this process, since it was in control of the institution of marriage, had to provide the legal means for the family's social needs. One of the consequences was a drop in the age limit between unconscious and conscious will, so that matrimonial engagements could be performed at an earlier stage.

This was a parallel process to the drop in the minimum age of moral responsibility and religious duties. The Church could, in addition, profit from such processes in recruiting younger novices at an earlier stage in their life. Hagiography responded to this sort of need by developing a moral privilege and an exemplary model for the child in the form of holy agency. This exemplary model is contrasted in hagiographic texts with descriptions of non-holy and wicked children, who behave in an unchristian way. ${ }^{109}$ Agency is thus attributed to children in relation to the responsibility that they are given. Since in this case it is a moral responsibility, the agency is defined in moral terms as well.

\section{To conclude}

In order to examine the subject of child's agency we have analysed the way in which the concept was constructed and enacted in relation to the economic, social and cultural aspects of Byzantine life. A child's agency in Byzantium was legitimized,

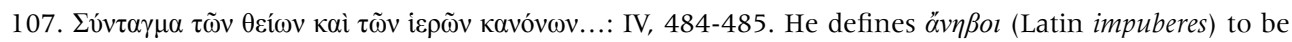
below fourteen years for boys, and below twelve for girls.

108. Patlagean, Évelyne. "L'enfant et son avenir..." : 85-93.

109. Kalogeras, Nikos. "What do they think about children?...": 10-19. See also: Abrahamse, Dorothy. "Images of Childhood...": 2-19. 
and enabled children to abandon their socio-economic position at home in favour of a spiritual Christian career. Namely, it defined a space for the child to express and carry into effect a very specific kind of will. Agency was attributed to the Byzantine child in order to construct moral capacities for the child that would serve a Christian agenda.

Moreover, in defining a limited space for the child to express a predetermined will, Byzantine society delegated an ethical responsibility to the child. This proves to be an essential element in the child's ability to possess agency. The Byzantine case demonstrates that when agency is attributed to the child, this is done for a specific objective which is ethically legitimized and defined as the 'right' one. Most pious children are presented in the Byzantine literature as diligent and hard-working, and do not think of leaving their home and family. Indeed, most Byzantine children probably did not run away. And as long as the children worked within their home, their work could not be differentiated and defined as a commodity. However, when hagiography sets a choice for the child to leave the house in favour of the monastery, it constructs a model of behaviour that is determined by the cultural ideals of the time and the social and economic needs that these ideals serve. Thus when a child's agency is defined, it is the agency to act in a predefined specific way. Once children worked outside their family household, their work was recognized as a commodity. Thus, a moral agenda that argues for the child to exert agency and to leave home, thus accorded with an economic objective to profit from the child's work.

This article started with the current debate on the question whether a child's will to participate in the labour market should be carried into effect, and whether its agency should be recognized and legitimized. The Byzantine case study shows that the socio-economic and moral-cultural aspects coincide in relation to the child's capacity to express a will of its own. This enables us to understand that a child's agency conceptualized in an economic framework, whether medieval or modern, masks a moral agenda that favours child employment. The question that we need to ask, therefore, is not whether to legitimize child labour, but why there is a call today to legitimize a child's will to labour. 